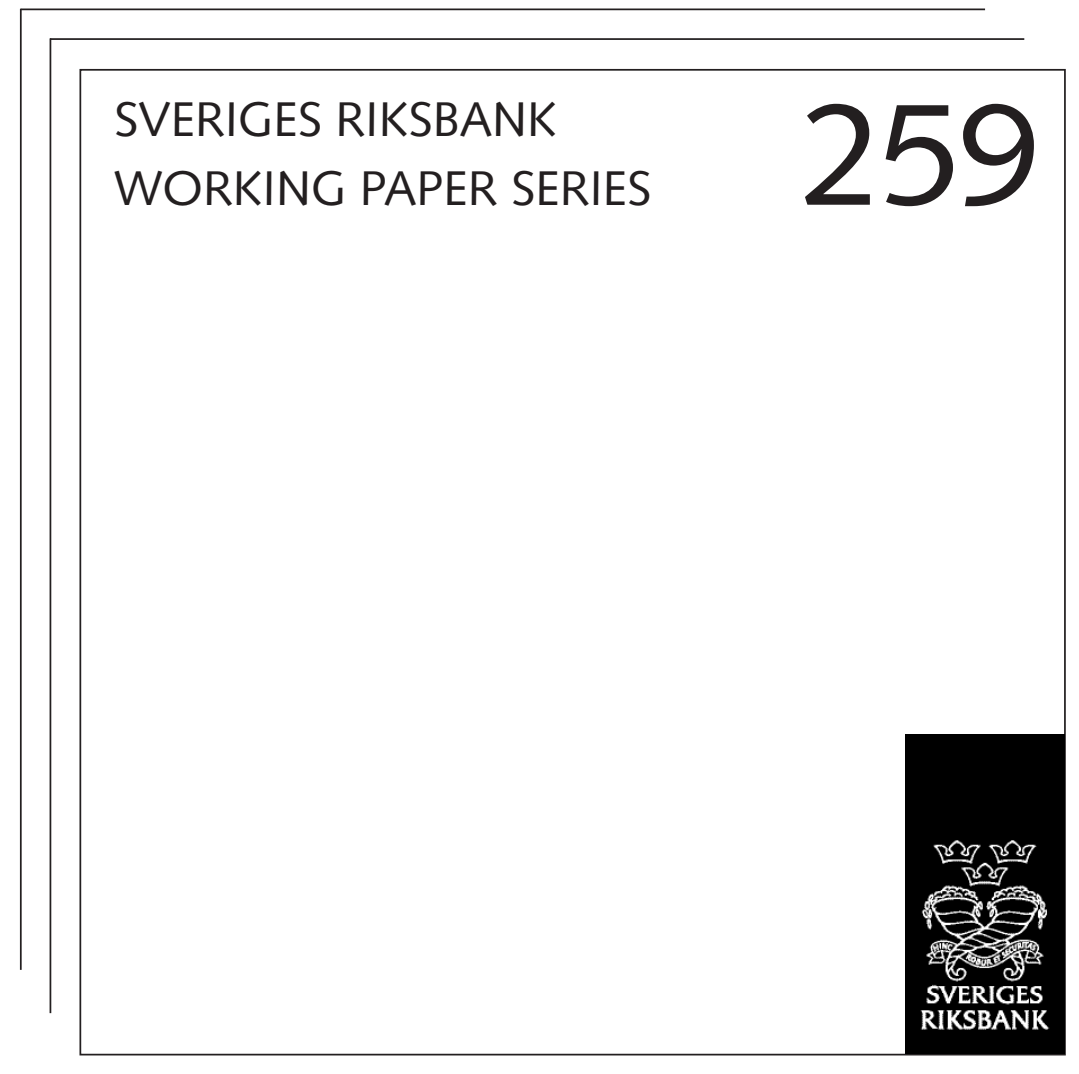

\title{
Labor-Market Frictions and Optimal Inflation
}

Mikael Carlsson and Andreas Westermark

MARCH 2012 


\section{WORKING PAPERS ARE OBTAINABLE FROM}

Sveriges Riksbank •Information Riksbank • SE-103 37 Stockholm Fax international: +4687870526

Telephone international: +4687870100

E-mail: info@riksbank.se

The Working Paper series presents reports on matters in the sphere of activities of the Riksbank that are considered to be of interest to a wider public.

The papers are to be regarded as reports on ongoing studies and the authors will be pleased to receive comments.

The views expressed in Working Papers are solely the responsibility of the authors and should not to be interpreted as reflecting the views of the Executive Board of Sveriges Riksbank. 


\title{
Labor-Market Frictions and Optimal Inflation*
}

\author{
Mikael Carlsson ${ }^{\dagger}$ and Andreas Westermark $k^{\ddagger}$ \\ Sveriges Riksbank Working Paper Series
}

No. 259

March 2012

\begin{abstract}
In central theories of monetary non-neutrality the Ramsey optimal inflation rate varies between the negative of the real interest rate and zero. This paper explores how the interaction of nominal wage and search and matching frictions affect the policy prescription. We show that adding the combination of such frictions to the canonical monetary model can generate an optimal inflation rate that is significantly positive. Specifically, for a standard U.S. calibration, we find a Ramsey optimal inflation rate of 1.11 percent per year.
\end{abstract}

Keywords: Optimal Monetary Policy, Inflation, Labor-market Distortions.

JEL classification: E52, H21, J60.

${ }^{*}$ We are grateful to Roberto Billi, Michael Krause, Per Krusell, Lars E.O. Svensson, Karl Walentin and participants at the Greater Stockholm Macro Group, JLS Seminar Series, Frankfurt, and the EEA Congress in Oslo, 2011, for useful comments and discussions. The views expressed in this paper are solely the responsibility of the authors and should not be interpreted as reflecting the views of the Executive Board of Sveriges Riksbank.

${ }^{\dagger}$ Research Department, Sveriges Riksbank, SE-103 37, Stockholm, Sweden. e-mail: mikael.carlsson@riksbank.se.

${ }^{\ddagger}$ Research Department, Sveriges Riksbank, SE-103 37, Stockholm, Sweden. e-mail: andreas.westermark@riksbank.se. 


\section{Introduction}

In leading theories of monetary non-neutrality, the policy prescription for the optimal steady state inflation rate varies between the negative of the real interest rate (the Friedman rule) and zero (price stability); see Schmitt-Grohe Uribe, 2010, for an overview. In this paper we explore a new channel where the interaction of nominal wage and labor market search and matching frictions affects the planner's trade-off between the welfare costs and benefits of inflation. We show that the combination of such frictions can in fact generate a Ramsey optimal inflation that is significantly positive. Importantly, this is the case even in the presence of a monetary friction, which drives the optimal inflation choice towards the Friedman rule of deflation.

The mechanism we have in mind arises when nominal wages are not continuously rebargained and some newly hired workers enter into an existing wage structure (due to e.g. fairness reasons). In this case, we show in a stylized model that inflation not only affects real-wage profiles over a contract spell, but also redistributes surplus between workers and firms through its effect on the workers' outside option. This affects the wage-bargaining outcome, the expected present value of total labor costs for a match and thus also firms' incentives for vacancy creation. The Ramsey planner then has incentives to increase inflation if employment and vacancy creation are inefficiently low in order to push the economy towards the efficient allocation. Note that in an efficient allocation this incentive vanishes (and the reverse occurs when employment is inefficiently high). Also, the Ramsey planner loses the ability to affect real wage costs via inflation if all new workers get to rebargain their wage. In this case, the full effect of inflation is internalized in the wage bargain and firm and worker surpluses, as well as real wage costs, become neutral to inflation.

To quantitatively evaluate the relative strength of this mechanism, we introduce it into a full-fledged model encompassing leading theories of monetary non-neutrality. The model we outline features a nonWalrasian labor market with search frictions as in Mortensen and Pissarides (1994), Trigari (2009) and Christoffel, Kuester, and Linzert (2009). Moreover, there are impediments to continuous resetting of nominal prices and wages modeled along the lines of Dotsey, King, and Wolman (1999), where adjustment probabilities are endogenous. Finally, the model features a role for money as a medium of exchange, as in Khan, King, and Wolman (2003) and Lie (2010).

In the model, variation in the average inflation rate will have several effects on welfare. First, inflation will affect the opportunity cost of holding money, pushing the optimal inflation rate towards the Friedman rule. Second, because of monopolistic competition and nominal frictions, inflation causes relative price distortions, which drive the optimal inflation rate towards zero. Thus, combining the monetary friction with the nominal price friction, as done by Khan, King, and Wolman (2003), SchmittGrohe Uribe $(2004,2005,2010)$ and Lie (2010), yields a negative optimal inflation rate somewhere 
between the Friedman rule and zero. Finally, we add that some newly hired workers may enter into an existing wage structure, giving rise to the mechanism outlined above.

In a standard U.S. calibration of the model, implying that employment is 2.85 percent lower than in the efficient allocation, we find that the Ramsey optimal inflation rate is 1.11 percent per year. Moreover, varying the share of new hires receiving rebargained wages has a substantial effect on the optimal inflation rate. If all newly hired workers receive rebargained wages, thus shutting down the interaction effect between nominal wage frictions and search and matching frictions, the optimal inflation rate is about -0.78 percent. ${ }^{1}$ When 80 [62.5, baseline] (50) percent of the newly hired workers receive new wages the optimal inflation rate changes to 0.45 [1.11] (1.35) percent. Thus, only a small share of new workers entering into an existing wage structure is needed to obtain a significantly positive optimal inflation rate.

When shutting down the monetary distortion and looking at the cashless economy, as analyzed in Woodford (2003), we find that the Ramsey optimal inflation rate increases to 1.96 percent. Thus, the monetary distortion has a substantial effect on the optimal policy prescription.

The results reported above are conditional on agents optimally choose when to change prices and wages. It is then interesting to study the effect of shutting down the endogenous response of the adjustment probabilities to variations in inflation and let the agents face a fixed adjustment hazard. In contrast to Lie (2010), we find that endogenizing adjustment probabilities matters for the quantitative analysis. Specifically, exogenous price and wage adjustment hazards give a Ramsey optimal inflation rate of 1.59 percent, thus an increase of almost half a percentage point relative to the case with endogenous adjustment hazards.

All in all, we find that adding the combination of search and matching frictions and staggered wage bargaining to the canonical monetary model introduces an important link between inflation and welfare and hence potentially a large difference in prescribed policy.

For clarity, the model outlined in this paper does not encompass all mechanisms that can affect the Ramsey optimal steady state inflation rate. Papers studying the effect of other mechanisms on the Ramsey optimal steady state inflation are Schmitt-Grohe and Uribe (2010), using inflation as an indirect tax to address tax evasion, Schmitt-Grohe and Uribe (2011) analyzing foreign demand of domestic currency, Schmitt-Grohe and Uribe (2009) studying quality bias, Adam and Billi (2006) and Billi (2011) looking into the effect of the zero lower bound, and Kim and Ruge-Murcia (2011)

\footnotetext{
${ }^{1}$ This is almost the same rate as if we let all wage contracts be continuously rebargained in the model (not only those of the new hires). These cases are virtually the same due to that wages are not allocative in the search matching framework we rely on, or more specifically, a relative-wage dispersion across firms does not give rise to a dispersion of labor supply across individuals working at different firms. The small difference stems instead from effects through the endogenous wage-adjustment probabilities.
} 
addressing downward nominal wage rigidity. ${ }^{2}$ Of these, only a substantial foreign demand of domestic currency and a planner that only cares about the well-being of the home country may lead to a significantly positive inflation rate. Moreover, all of these features are, if anything, likely to drive up the Ramsey optimal steady state inflation rate. Thus, in this sense the results presented here can be viewed as a lower bound.

This paper is outlined as follows; in section 2 we present the basic mechanism we have in mind, in section 3, we outline the framework for the quantitative evaluation, including a description of the optimal Ramsey policy, in section 4 the calibration and the quantitative results are presented. Finally, section 5 concludes.

\section{The Mechanism}

To set ideas, it is helpful to first focus on a stylized partial equilibrium model of the labor market featuring the interaction mechanism we have in mind. Let firms and workers sign contracts with a fixed (nominal) wage, $W$, that with certainty lasts for two periods. Letting $P$ denote the price level in the first period of the contract and $\pi$ the gross inflation rate, the real wage in the first and second periods of the contract, respectively, are then $w=\frac{W}{P}$ and $w^{\prime}=\frac{W}{\pi P}=\frac{w}{\pi}$. This captures the first component we need, i.e. nominal wage frictions. Secondly, we assume that there are search and matching frictions, giving rise to a surplus to be bargained over. The value for the firm at the period where wages are rebargained is then

$$
J_{0}=p^{w}-w+\beta \rho J_{1}
$$

where $p^{w}$ is the (real) marginal revenue for the firm, $\beta$ is the discount factor and $\rho$ is the fixed probability that the match survives into the next period. Moreover,

$$
J_{1}=p^{w}-\frac{w}{\pi}+\beta \rho J_{0}
$$

is the value one period after the contract was signed. Similarly, the values for the worker are

$$
\begin{aligned}
& H_{0}=w-b_{r}+\beta\left[\rho H_{1}-s H_{x}\right] \\
& H_{1}=\frac{w}{\pi}-b_{r}+\beta\left[\rho H_{0}-s H_{x}\right],
\end{aligned}
$$

\footnotetext{
${ }^{2}$ There is also a literature focusing on the dynamic effects of labor-market frictions under the Ramsey optimal policy; see Faia (2009), Faia and Rossi (2009) and Thomas (2008).
} 
where $b_{r}$ is (real) income received when unemployed and $H_{x}$ is the average value of being employed across all firms in the economy. Note that variations in $H_{x}$ affect the workers' outside option in the bargain. Using the value functions $J_{1}$ and $H_{1}$ gives

$$
\begin{aligned}
J_{0} & =p^{w}-w+\beta \rho\left(p^{w}-\frac{w}{\pi}+\beta \rho J_{0}\right) \\
H_{0} & =w-b_{r}+\beta\left[\rho\left(\frac{w}{\pi}-b_{r}+\beta\left[\rho H_{0}-s H_{x}\right]\right)-s H_{x}\right] .
\end{aligned}
$$

Case 1: New hires get new wages

If newly hired workers get new wages then $H_{x}=H_{0}$. When bargaining, we set $H_{0}=\frac{\varphi}{1-\varphi} J_{0}$ where $\varphi$ is the bargaining power of the worker, and thus

$$
w+\frac{\beta \rho}{\pi} w=f\left(p^{w}, \beta, \rho, b_{r}, s\right)
$$

Hence, for given values of $p^{w}, \beta, \rho, b_{r}$ and $s$, changes in the inflation rate will not affect the discounted real wage sum, implying that the value of the firm $J_{0}$ is independent of the inflation rate. Hence, an increase in the inflation rate leads to an exactly offsetting increase in the wage $W$. In turn, since $J_{0}$ is unaffected, vacancy-creation incentives are also unaffected. Note also that the value of the firm is the same as when wages are fully flexible, implying that the job creation condition is the same as with flexible wages. To see this, when wages are flexible, values are

$$
\begin{aligned}
J_{0} & =p^{w}-w+\beta \rho J_{0} \\
H_{0} & =w-b_{r}+\beta\left[\rho H_{0}-s H_{x}\right] .
\end{aligned}
$$

Solving for the wage using $H_{0}=\frac{\varphi}{1-\varphi} J_{0}$ implies that

$$
J_{0}=\frac{1}{1-\beta \rho+\frac{\varphi}{1-\varphi}(1-\beta(\rho-s))}\left(p^{w}-b_{r}\right) .
$$

When nominal wages are sticky, the solution for $J_{0}$ is the same, as can be seen from using (4) and $H_{0}=\frac{\varphi}{1-\varphi} J_{0}$ to solve for the wage costs $w+\frac{\beta \rho}{\pi} w$ and computing $J_{0}$.

Case 2: Not all new hires get new wages

When newly hired workers can get the inflation-eroded wage $\frac{w}{\pi}$ instead of $w$ with some probability, the neutrality result above breaks down. In case inflation is positive, newly hired workers get a lower 
expected wage, holding $w$ constant. When for example $H_{x}=\frac{1}{2} H_{0}+\frac{1}{2} H_{1}$, one can show that

$$
\begin{aligned}
J_{0} & =\frac{1}{1-(\beta \rho)^{2}}\left(p^{w}-w+\beta \rho\left(p^{w}-\frac{w}{\pi}\right)\right) \\
H_{0} & =\frac{1}{1-\beta^{2} \frac{\left(\rho-\frac{s}{2}\right)^{2}}{1+\beta \frac{s}{2}}-\beta \frac{s}{2}}\left(w-b_{r}+\beta\left[\frac{\rho-\frac{s}{2}}{1+\beta \frac{s}{2}}\left(\frac{w}{\pi}-b_{r}\right)\right]\right) .
\end{aligned}
$$

When setting $H_{0}=\frac{\varphi}{1-\varphi} J_{0}$ and solving, the firms total discounted wage costs, $\left(1+\frac{\beta \rho}{\pi}\right) w$, now depends on the inflation rate, in contrast to expression (5). Then, in turn, the firm value is affected by the inflation rate. ${ }^{3}$ The intuition is the following; since increases in inflation decrease the outside option of workers, this leads to an increase in the firm value and hence an improvement in vacancycreation incentives. In a general equilibrium model, a Ramsey planner then has incentives to vary the inflation rate in order to affect equilibrium unemployment and, in turn, welfare. However, to realistically evaluate the quantitative importance of this mechanism, we need to embed it in the canonical monetary model.

\section{A Model for Quantitative Evaluation}

The basic framework for the quantitative evaluation shares many elements of standard models. There is a monopolistically competitive intermediate goods sector where producers set prices facing a stochastic fixed adjustment cost as in Dotsey, King, and Wolman (1999). The intermediate goods sector buys a homogenous input from the wholesale sector, which, in turn, uses labor in the production of this input. ${ }^{4}$ The market for this homogenous input is characterized by perfect competition.

In contrast to previous papers studying the Ramsey optimal inflation rate, our model features search and matching frictions and staggered wage bargaining. Specifically, the wholesale sector posts vacancies on a search and matching labor market similar to Christoffel, Kuester, and Linzert (2009) and Trigari (2009). Wages are bargained between a representative family and wholesale firms in a setting with stochastic impediments to rebargaining, akin to how price setting is modeled. The representative family construct, composed of many workers as in Merz (1995), is introduced to ensure complete consumption insurance. The representative family then supplies labor, bargains wages and assures

\footnotetext{
${ }^{3}$ In general, the solution is rather complicated. As a special case, when $\beta=1$ and the bargaining power of firms and workers is equal, the solution for $J_{0}$ is given by

$$
J_{0}=\frac{1}{1-(\rho)^{2}} \frac{p^{w}(1+\rho)\left(1+(\rho)^{2}\left(1+\frac{\rho-\frac{s}{2}}{1+\frac{s}{2}} \frac{1}{\pi}\right)\right)-\left(1+(\rho)^{2}\right)\left(1+\frac{\rho-\frac{s}{2}}{1+\frac{s}{2}}\right) b_{r}\left(1+\frac{\rho}{\pi}\right)}{1+(\rho)^{2}\left(1+\frac{\rho-\frac{s}{2}}{1+\frac{s}{2}} \frac{1}{\pi}\right)+\left(1-\frac{\left(\rho-\frac{s}{2}\right)^{2}}{1+\frac{s}{2}}-\frac{s}{2}\right)\left(1+\frac{\rho}{\pi}\right)}
$$

i.e., $J_{0}$ depends on $\pi$.

${ }^{4}$ For simplicity, we abstract from capital accumulation. Thus, our model is equivalent to a model with fixed firmspecific capital.
} 
equal consumption across workers within the family. Finally, notation is simplified by assuming a flexible-price retail sector that repacks the intermediate goods in accordance with consumer preferences and sells them to the representative family on a competitive market.

\subsection{Intermediate-Goods Firms}

The intermediate-goods firm chooses whether to adjust prices or not. Let the probability of adjusting prices in a given period be denoted by $\alpha_{t}^{j}$, given that the firm last adjusted its price $j$ periods ago. For technical reasons, we assume that there is some $J>1$ such that $\alpha^{J-1}=1$. Note that we follow standard notation and label the $J$ cohorts from 0 to $J-1$.

\subsubsection{Prices}

Given that an intermediate-goods firm last reset prices in period $t-j$, the maximum duration of the price contract is then $J-j$, where $J$ is the maximum price contract duration and $\alpha_{t}^{j}$ is the adjustment probability $j$ periods after the price was last reset. The intermediate-goods firms buys a homogeneous input from the wholesale firms at the (real) price $p_{t}^{w}$. As in Khan, King, and Wolman (2003), an intermediate producer chooses the optimal price $P_{t}^{0}$ so that

$$
\begin{aligned}
v_{t}^{0}= & \max _{P_{t}^{0}}\left[\frac{P_{t}^{0}}{P_{t}}-p_{t}^{w}\right] Y_{t}^{0}+E_{t} \Lambda_{t, t+1} \beta\left(\alpha_{t+1}^{1} v_{t+1}^{0}+\left(1-\alpha_{t+1}^{1}\right) v_{t+1}^{1}\left(\frac{P_{t}^{0}}{P_{t+1}}\right)\right) \\
& -E_{t} \Lambda_{t, t+1} \beta p_{t+1}^{w} \Xi_{1, t+1},
\end{aligned}
$$

where

$$
Y_{t}^{j}=\left(\frac{P_{t}^{j}}{P_{t}}\right)^{-\sigma} Y_{t},
$$

and where $P_{t}$ is the aggregate intermediate goods price level and $\beta$ the discount factor. Moreover, $\Lambda_{t, t+1}$ is the ratio of Lagrange multipliers in the problem of the consumer tomorrow and today. Finally, $\Xi_{1, t+1}$ is the expected adjustment costs. Note that the term within the square brackets is just the firm's per unit profit in period $t$.

The values $v_{t}^{j}$ evolve according to

$$
\begin{aligned}
v_{t}^{j}\left(\frac{P_{t}^{j}}{P_{t}}\right)= & {\left[\frac{P_{t}^{j}}{P_{t}}-p_{t}^{w}\right] Y_{t}^{j}+E_{t} \Lambda_{t, t+1} \beta\left(\alpha_{t+1}^{j+1} v_{t+1}^{0}+\left(1-\alpha_{t+1}^{j+1}\right) v_{t+1}^{j+1}\left(\frac{P_{t}^{j}}{P_{t+1}}\right)\right) } \\
& -E_{t} \Lambda_{t, t+1} \beta p_{t+1}^{w} \Xi_{j+1, t+1}, \\
v_{t}^{J-1}\left(\frac{P_{t}^{J-1}}{P_{t}}\right)= & {\left[\frac{P_{t}^{J-1}}{P_{t}}-p_{t}^{w}\right] Y_{t}^{J-1}+E_{t} \Lambda_{t, t+1} \beta v_{t+1}^{0}-E_{t} \Lambda_{t, t+1} \beta p_{t+1}^{w} \Xi_{J, t+1} . }
\end{aligned}
$$

We model price-adjustment probabilities as in Dotsey, King, and Wolman (1999) and others. Thus, 
adjustment probabilities are chosen endogenously by the firm and are one if $c_{p, t}^{j}<\frac{v_{t}^{0}-v_{t}^{j}}{p_{t}^{w}}$ and zero if $c_{p, t}^{j}>\frac{v_{t}^{0}-v_{t}^{j}}{p_{t}^{w}}$. Adjustment costs are drawn from a cumulative distribution function $G_{P}$ with upper bound $\Omega_{P}$. The maximal cost $c_{p, t}^{j, \max }$ for a cohort $j$ at time $t$ that induces price changes is then $c_{p, t}^{j, \max }=\frac{v_{t}^{0}-v_{t}^{j}}{p_{t}^{w}}$ and we can thus express the expected adjustment costs as

$$
\Xi_{j, t}=\int_{0}^{c_{p, t}^{j, \max }} c_{p} d G_{P}\left(c_{p}\right)
$$

The share of firms among those that last adjusted the price $j$ periods ago that adjusts the price today is then given by

$$
\alpha_{t}^{j}=G_{P}\left(c_{p, t}^{j, \max }\right)
$$

The first-order condition to problem (9) is

$$
\left[(1-\sigma) \frac{P_{t}^{0}}{P_{t}}+\sigma p_{t}^{w}\right] Y_{t}^{0} \frac{1}{P_{t}}+E_{t} \Lambda_{t, t+1} \beta\left(\left(1-\alpha_{t+1}^{1}\right) D_{1} v_{t}^{1}\left(\frac{P_{t}^{0}}{P_{t+1}}\right) \frac{1}{P_{t+1}}\right)=0
$$

where, noting that $P_{t+j}^{j}=P_{t}^{0}$, the derivative $D_{1} v_{t}^{1}$ can be computed by using

$$
\begin{aligned}
D_{1} v_{t}^{j} & =\left[(1-\sigma) \frac{P_{t}^{j}}{P_{t}}+\sigma p_{t}^{w}\right] \frac{Y_{t}^{j}}{P_{t}}+E_{t} \Lambda_{t, t+1} \beta\left(\left(1-\alpha_{t+1}^{j+1}\right) D_{1} v_{t+1}^{j+1}\left(\frac{P_{t}^{j}}{P_{t+1}}\right) \frac{1}{P_{t+1}}\right), \\
D_{1} v_{t}^{J-1} & =\left[(1-\sigma) \frac{P_{t}^{J-1}}{P_{t}}+\sigma p_{t}^{w}\right] \frac{Y_{t}^{J-1}}{P_{t}} .
\end{aligned}
$$

Thus, optimal pricing behavior is fully characterized by expressions (14) and (15).

The share of firms with duration $j$ since the last price change is denoted by $\omega_{t}^{j}$. For $j \geq 1$ the shares evolve as

$$
\omega_{t}^{j}=\left(1-\alpha_{t}^{j}\right) \omega_{t-1}^{j-1}
$$

and, the share of firms with newly set prices $\left(\omega_{t}^{0}\right)$ in period $t$ will be

$$
\omega_{t}^{0}=\sum_{j=1}^{J-1} \alpha_{t}^{j} \omega_{t-1}^{j-1}
$$

\subsection{Retailers}

The retail firm buy intermediate goods and repackages them as final goods. We follow Erceg, Henderson, and Levin (2000) and Khan, King, and Wolman (2003) and assume a competitive retail sector selling a composite good. The composite good is combined from intermediate goods in the same proportions as families would choose. Given intermediate goods output levels $Y_{t}^{j}$, produced by 
intermediate-goods firms in each cohort $j$, the amount of the composite good $Y_{t}$ is

$$
Y_{t}=\left[\sum_{j=0}^{J-1} \omega_{t}^{j}\left(Y_{t}^{j}\right)^{\frac{\sigma-1}{\sigma}}\right]^{\frac{\sigma}{\sigma-1}}
$$

where $\sigma>1$ and $\omega_{t}^{j}$ is the share of retail firms producing $Y_{t}^{j}$ at price $P_{t}^{j}$. The price $P_{t}$ of one unit of the composite good is

$$
P_{t}=\left[\sum_{j=0}^{J-1} \omega_{t}^{j}\left(P_{t}^{j}\right)^{1-\sigma} d f\right]^{\frac{1}{1-\sigma}}
$$

As in Khan, King, and Wolman (2003), the retailers need to borrow to finance current production and choose $\left\{Y_{t}^{j}\right\}_{j=0}^{J}$ to minimize costs for a given amount $Y_{t}$ of final goods created. Thus, retailers solve

$$
\min _{\left\{Y_{t}^{j}\right\}_{j=0}^{J}}\left(1+R_{t}\right) P_{t} \sum_{j=0}^{J-1} \omega_{t}^{j} p_{t}^{j} Y_{t}^{j},
$$

where $\left(1+R_{t}\right)$ is the gross nominal interest rate, subject to (18), implying that the price level of the retailers is $\bar{P}_{t}=\left(1+R_{t}\right) P_{t}$ and hence

$$
\bar{p}_{t}=\frac{\bar{P}_{t}}{P_{t}}=\left(1+R_{t}\right)
$$

\subsection{Families}

To introduce a demand for money in the model, we follow Khan, King, and Wolman (2003) and assume that agents use either credit or money to purchase consumption goods. Specifically, families purchase a fraction $\xi_{t}$ of consumption with credit goods. Using credit requires paying a stochastic fixed time cost, drawn from a cumulative distribution $F$, with upper bound $\Omega_{c}$, and hence $\xi_{t}=\int_{0}^{\bar{c}} d F(x)$ where $\bar{c}$ is the maximal credit cost paid by the family for a consumption good (for a detailed discussion see Khan, King and Wolman, 2003). The amount of labor used in obtaining credit is denoted $h_{t}^{c}$. The total time cost of credit for the family is then

$$
h_{t}^{c}=\int_{0}^{\bar{c}} x d F(x)
$$

Families have preferences

$$
E_{t} \sum_{t=t_{0}}^{\infty} \beta^{t-t_{0}}\left[u\left(c_{t}\right)+\sum_{j^{w}=0}^{J_{w}-1} n_{t}^{j_{w}} \kappa^{L} \frac{\left(1-\bar{h}-h_{t}^{c}\right)^{1-\phi}}{1-\phi}+\left(1-n_{t}\right) \kappa^{L} \frac{\left(1-h_{t}^{c}\right)^{1-\phi}}{1-\phi}\right]
$$

where $\bar{h}$ denotes the workers' hours worked at a wholesale firm, $c_{t}$ consumption, $n_{t}^{j_{w}}$ the number of 
employees in wage cohort $j_{w}$ and $n_{t}$ aggregate employment. Families hold an aliquot share of all firms. The budget constraint of the family is given by

$$
M_{t}+\frac{1}{1+R_{t}} B_{t+1} \geq B_{t}-D_{t}-T_{t}+\mathcal{W}_{t}
$$

where $P_{t}$ is the price level, $M_{t}$ is money holdings, $B_{t}$ bonds, $D_{t}$ credit debt, $T_{t}$ consists of lump sum transfers from the government and firm dividends, $R_{t}$ is the one period nominal interest rate between period $t$ and $t+1$ and

$$
\mathcal{W}_{t}=\sum_{j^{w}=0}^{J_{w}-1} n_{t}^{j_{w}} W_{t}^{j_{w}} \bar{h}+\left(1-n_{t}\right) P_{t} b_{r}
$$

with $P_{t} b_{r}$ being the unemployment benefits. Moreover, $W_{t}^{j_{w}}$ denotes the workers' nominal wage in wage cohort $j_{w}$ and $1-n_{t}$ is equal to the unemployment rate. In real terms

$$
m_{t}+\frac{1}{1+R_{t}} b_{t+1} \geq \frac{b_{t}-d_{t}}{1+\pi_{t}}-\tau_{t}+\frac{\mathcal{W}_{t}}{P_{t}}
$$

where $m_{t}=\frac{M_{t}}{P_{t}}, b_{t+1}=\frac{B_{t+1}}{P_{t}}, d_{t}=\frac{D_{t}}{P_{t-1}}, \tau_{t}=\frac{T_{t}}{P_{t}}$ and $\pi_{t}$ is the inflation rate between period $t-1$ and $t$. Since agents purchase a fraction $1-\xi_{t}$ of consumption goods, the demand for money is

$$
m_{t}=\left(1-\xi_{t}\right) \bar{p}_{t} c_{t}
$$

Similarly, we have that the real credit debt to be paid in period $t+1$ is $d_{t+1}=\xi_{t} \bar{p}_{t} c_{t}$. Using credit requires paying a stochastic fixed time cost. This cost is realized after the family has decided on the amount of a product to buy but before choosing between credit or money as means of payment. Here, credit is defined as a one-period interest rate free loan that needs to be repaid in full the next period. Families then choose to use credit as long as the gain, $R_{t} c_{t}$, is larger than the cost of credit. ${ }^{5}$

The family's first-order conditions with respect to $c_{t}$ and $\xi_{t}$ are, using that $\bar{p}_{t}=\left(1+R_{t}\right)$,

$$
\begin{array}{ll}
c_{t}: & u_{c}\left(c_{t}\right)=\lambda_{t}\left(1+R_{t}\left(1-\xi_{t}\right)\right) \\
\xi_{t}: & \lambda_{t} R_{t} c_{t}=\left[n_{t} \kappa^{L}\left(1-\bar{h}-h_{t}^{c}\right)^{\phi}+\left(1-n_{t}\right) \kappa^{L}\left(1-h_{t}^{c}\right)^{\phi}\right] F^{-1}\left(\xi_{t}\right),
\end{array}
$$

where $F^{-1}\left(\xi_{t}\right)$ is the realization of the credit cost in terms of time.

Using the envelope theorem and the first-order condition with respect to $b_{t+1}$ we can write the

\footnotetext{
${ }^{5}$ That is, the real discounted net gain of placing the transaction amount in a bond for a period and repay the transaction amount the next period. To see this, combine the first-order condition with respect to $\xi(28)$ together with the Euler equation (29), below.
} 
family Euler equation as

$$
\frac{\lambda_{t}}{1+R_{t}}=\beta E_{t} \frac{\lambda_{t+1}}{1+\pi_{t+1}}
$$

\subsection{Search and Matching}

As in Christoffel, Kuester, and Linzert (2009), the wholesale firm in cohort $j^{w}$ posts $\nu_{t}^{j_{w}}$ vacancies and employs $n_{t}^{j_{w}}$ workers. The aggregate number of vacancies is

$$
v_{t}=\sum_{j^{w}=0}^{J_{w}-1} \nu_{t}^{j_{w}},
$$

and aggregate employment is

$$
n_{t}=\sum_{j^{w}=0}^{J_{w}-1} n_{t}^{j_{w}},
$$

and the number of unemployed workers is

$$
u_{t}=1-n_{t}
$$

We assume that the number of matches, $\mu_{t}$, is given by the following constant-returns matching function

$$
\mu_{t}=\sigma_{\mu}\left(u_{t-1}\right)^{\sigma_{a}} \nu_{t}^{1-\sigma_{a}}
$$

Note that we assume that matches are formed out of current-period vacancies and the initial stock of unemployed, $u_{t-1}$. The probability that a worker is matched to a firm is

$$
s_{t}=\frac{\mu_{t}}{u_{t-1}}
$$

and the probability that a vacancy is filled is

$$
q_{t}=\frac{\mu_{t}}{\nu_{t}}
$$

Finally, a match is broken with probability $1-\rho$.

\subsection{Bargaining}

Previous models studying the Ramsey optimal inflation rate features flexible, e.g. Khan, King, and Wolman (2003), or non-staggered wages, e.g. Kim and Ruge-Murcia (2011). Here, however, we aim at introducing staggered state-dependent wage bargaining, as in price setting. To accomplish this within a microfounded bargaining model, we rely on the bargaining framework of Haller and Holden (1990) 
and Holden (1994). However, in order to end up in a wage-setting formulation that is comparable to standard search and matching models we slightly modify their set-up. Specifically, we replace the conflict subgame in figure 1 in Haller and Holden (1990) by a subgame where there is a positive probability of breakdown.

In the model, the parties bargain every period. Each bargaining round starts with one of the parties making a bid, then the other party responds yes or no. If the response is no, there is a choice whether to continue bargaining in good faith and post a counter offer or enter into disagreement. If the latter choice is made, there is a probability that the match breaks down and the wage is determined in a standard Rubinstein-Ståhl fashion. Moreover, in case a party initiate bargaining under disagreement, both parties face their own known fixed disagreement cost (randomly drawn at the beginning of each period). As in Holden (1994), this cost may be due to deteriorating firm/worker and customer relationships. In case none of the parties chooses to bargain under disagreement, but are unable to settle on a new wage, work continues according to the old contract. If the disagreement cost is sufficiently high, it is not credible for a party to threaten with disagreement in order to achieve a new wage contract. Instead, the outcome will be to continue to work according to the old contract already in place, and the model thus generates nominal wage rigidities as a rational endogenous outcome.

Note that there is no disagreement in equilibrium, and hence the equilibrium disagreement costs is zero. Thus, in contrast to price adjustment costs, this cost neither enter resource constraints nor firm/worker value functions. Moreover, this cost is of no direct concern to the Ramsey planner, although it affects the optimal solution indirectly through its impact on private sector behavior.

\subsection{Wage Determination}

Wages are adjusted with probability $\alpha_{t}^{j_{w}}$ in the $j_{w}$ th period following the last rebargain, with $\alpha_{t}^{J_{w}-1}=1$ for some $J_{w}>1$.

\subsubsection{Value Functions}

The value in period $t$ for the family of a worker at a wholesale firm where the wage was last rebargained in period $t-j_{w}$ is ${ }^{6}$

$$
\begin{aligned}
V_{t}^{j_{w}}\left(w_{t}^{j_{w}}\right)= & w_{t}^{j_{w}} \bar{h}-\kappa^{L} \frac{\left(1-\bar{h}-h_{t}^{c}\right)^{1-\phi}}{(1-\phi) \lambda_{t}}+\beta E_{t} \Lambda_{t, t+1}\left(\rho \alpha_{t+1}^{j_{w}+1} V_{t+1}^{0}\left(w_{t+1}^{0}\right)\right) \\
& +\beta E_{t} \Lambda_{t, t+1}\left(\rho\left(1-\alpha_{t+1}^{j_{w}+1}\right) V_{t+1}^{j_{w}+1}\left(w_{t+1}^{j_{w}+1}\right)+(1-\rho) U_{t+1}\right),
\end{aligned}
$$

\footnotetext{
${ }^{6}$ This follows from taking the derivative of the family value in (23) with respect to $n_{t}^{j_{w}}$.
} 
where $w_{t}^{j_{w}}$ is the real wage and $h_{t}^{j_{w}}$ hours worked. The value when being unemployed is

$$
U_{t}=b_{r}-\kappa^{L} \frac{\left(1-h_{t}^{c}\right)^{1-\phi}}{(1-\phi) \lambda_{t}}+\beta E_{t} \Lambda_{t, t+1}\left(s_{t+1} V_{x, t+1}+\left(1-s_{t+1}\right) U_{t+1}\right)
$$

where $V_{x, t}$ is average value of employment across firms. As in the stylized model above in section 2, whether newly hired workers get new rebargained wages or enter into a given wage structure of the firm affects the value of $V_{x, t}$ and hence the family's outside option. Specifically, if newly hired workers get rebargained wages we have

$$
V_{x, t}^{n e w}=V_{t}^{0}\left(w_{t}^{0}\right)
$$

and if workers enter a given wage structure in a firm, where $\varpi_{t}^{j_{w}}$ denotes the share of employed workers in cohort $j_{w}$,

$$
V_{x, t}^{g i v}=\sum_{j_{w}=0}^{J_{w}-1} \varpi_{t}^{j_{w}} V_{t}^{j_{w}}\left(w_{t}^{j_{w}}\right) .
$$

In the model, we let the share of new hires that get a rebargained wage be a free parameter. If $s^{\text {new }}$ is the share getting new rebargained wages we thus have

$$
V_{x, t}=s^{\text {new }} V_{x, t}^{\text {new }}+\left(1-s^{\text {new }}\right) V_{x, t}^{\text {giv }}
$$

The expected net surplus for the family to have a worker employed in a wholesale firm that last rebargained wages $j_{w}$ periods ago is

$$
H_{t}^{j_{w}}\left(w_{t}^{j_{w}}\right)=V_{t}^{j_{w}}\left(w_{t}^{j_{w}}\right)-U_{t}
$$

and hence, using (36) and (37), the value of an additional employee for the family can then be written as

$$
\begin{aligned}
H_{t}^{j_{w}}\left(w_{t}^{j_{w}}\right)= & w_{t}^{j_{w}} \bar{h}-b_{r}-\kappa^{L} \frac{\left(1-\bar{h}-h_{t}^{c}\right)^{1-\phi}}{(1-\phi) \lambda_{t}}+\kappa^{L} \frac{\left(1-h_{t}^{c}\right)^{1-\phi}}{(1-\phi) \lambda_{t}} \\
& +\beta E_{t} \Lambda_{t, t+1}\left[\rho \alpha_{t+1}^{j_{w}+1} H_{t+1}^{0}\left(w_{t+1}^{0}\right)+\rho\left(1-\alpha_{t+1}^{j_{w}+1}\right) H_{t+1}^{j_{w}}\left(w_{t+1}^{j_{w}+1}\right)-s_{t+1} H_{x, t+1}\right]
\end{aligned}
$$

where $\left.H_{x}\left(=V_{x}-U\right)\right)$ is the net value of getting a job in an average wholesale firm.

The wholesale firm in cohort $j_{w}$ uses labor $n_{t}^{j_{w}}$ as input to produce output $y_{t}^{j_{w}}$, using the constant returns technology,

$$
y_{t}^{j_{w}}=n_{t}^{j_{w}} Z \bar{h}
$$

with $Z$ being a level shifter of productivity. For the wholesale firm, the value of an additional employee 


$$
\begin{aligned}
J_{t}^{j_{w}}\left(w_{t}^{j_{w}}\right)= & p_{t}^{w} y_{t}^{j_{w}}-w_{t}^{j_{w}} \bar{h}-\Phi_{L}-\Phi_{K}+\beta E_{t} \Lambda_{t, t+1} \alpha_{t+1}^{j_{w}+1}\left(\rho J_{t+1}^{0}\left(w_{t+1}^{0}\right)\right) \\
& +\beta E_{t} \Lambda_{t, t+1}\left(1-\alpha_{t+1}^{j_{w}+1}\right) \rho J_{t+1}^{j_{w}+1}\left(w_{t+1}^{j_{w}+1}\right)
\end{aligned}
$$

where $\Phi_{L}$ and $\Phi_{K}$ are fixed labor and capital costs, modelled as in Christoffel, Kuester, and Linzert (2009). In effect, these costs reduce the surplus of the firm and increase the sensitivity of the surplus, and thus hiring incentives, to economic shocks. The difference between $\Phi_{L}$ and $\Phi_{K}$ is that $\Phi_{L}$, in contrast to $\Phi_{K}$, is treated as pure waste and also enter into the resource constraint (53) below; see Christoffel, Kuester, and Linzert (2009) for a further discussion. In practice, they are helpful in obtaining an empirically meaningful calibration of the model.

\subsubsection{Wage Bargaining}

The wage is determined in bargaining between the wholesale firms and the family. Relying on the equivalence between the standard non-cooperative approach in Rubinstein (1982) and the Nash bargaining approach, we employ the latter method. In case it is credible to threaten to enter into disagreement, the nominal wage $W_{i t}^{0}$ is chosen such that is solves the Nash product

$$
\max _{W_{i t}^{0}}\left(H_{t}^{0}\left(w_{t}^{0}\right)\right)^{\varphi}\left(J_{t}^{0}\left(w_{t}^{0}\right)\right)^{1-\varphi}
$$

where $w_{i t}^{0}=\frac{W_{i t}^{0}}{P_{t}}$ and $\varphi$ denotes the bargaining power of the family. The first-order condition with respect to the nominal wage $W_{i t}^{0}$ corresponding to $(45)$ is

$$
\varphi J_{t}^{0}\left(w_{t}^{0}\right) D_{W} H_{t}^{0}\left(w_{t}^{0}\right)+(1-\varphi) H_{t}^{0}\left(w_{t}^{0}\right) D_{W} J_{t}^{0}\left(w_{t}^{0}\right)=0
$$

where the derivatives $D_{W} H_{t}^{0}\left(w_{i t}^{0}\right)$ and $D_{W} J_{t}^{0}\left(w_{i t}^{0}\right)$ are computed using expressions (42) and (44).

The derivatives of the value functions are slightly different from those pertaining to price setting; c.f. equation (15). This is because the disagreement cost are not paid in equilibrium in wage setting, in contrast to adjustment costs in price setting. ${ }^{7}$ The derivative of the family (firm) value function then has an additional term consisting of the derivative of the adjustment probabilities. The derivative

\footnotetext{
${ }^{7}$ In price setting the effect of prices on adjustment probabilities are eliminated through the additional effects on adjustment costs $\Xi_{j, t}$ (which are not present in the value equations (42) and (44)), using an envelope argument. Note also that wages are not chosen to maximize either (42) or (44), but a weighted average of these two; see (46).
} 
of the family value function is then

$$
\begin{aligned}
\frac{\partial H_{t}^{j_{w}}\left(w_{t}^{j_{w}}\right)}{\partial W^{0}} \frac{1}{P_{t}}= & \frac{1}{P_{t}} \bar{h}+\beta E_{t} \frac{\lambda_{t+1}}{\lambda_{t}}\left[\rho\left(1-\alpha_{t+1}^{j_{w}+1}\right) \frac{\partial H_{t+1}^{j_{w}+1}\left(w_{t+1}^{j_{w}+1}\right)}{\partial W^{0}} \frac{1}{P_{t+1}}\right. \\
& \left.-\frac{\partial \alpha_{t+1}^{j_{w}+1}}{\partial W^{0}}\left(H_{t+1}^{j_{w}+1}\left(w_{t+1}^{j_{w}+1}\right)-H_{t+1}\left(w_{t+1}^{0}\right)\right) \frac{1}{P_{t+1}}\right]
\end{aligned}
$$

and the derivative of the value function for the firm is computed similarly.

The disagreement costs, drawn at the start of time period $t$, for the firm follow the cumulative distribution function $G_{J}$ and the cost of the family follows the cumulative distribution function $G_{H}$ with upper bounds $\Omega_{J}$ and $\Omega_{H}$, respectively. The adjustment probabilities depend on both $G_{J}\left(d J_{t}^{j_{w}}\left(w_{t}^{j_{w}}\right)\right)$ and $G_{H}\left(d H_{t}^{j_{w}}\left(w_{t}^{j_{w}}\right)\right)$ where the difference in the firm's value between adjusting the wage or not is

$$
d J_{t}^{j_{w}}\left(w_{t}^{j_{w}}\right)=J_{t}^{0}\left(w_{t}^{0}\right)-J_{t}^{j_{w}}\left(w_{t}^{j_{w}}\right)
$$

and similarly for the family

$$
d H_{t}^{j_{w}}\left(w_{t}^{j_{w}}\right)=H_{t}^{0}\left(w_{t}^{0}\right)-H_{t}^{j_{w}}\left(w_{t}^{j_{w}}\right)
$$

A detailed description of how these objects are computed is given in appendix B.

\subsection{The Hiring Decision and Employment Flows}

Wholesale firms in cohort $j_{w}$ choose vacancies $\nu_{t}^{j_{w}}$, after disagreement costs are drawn, so that the vacancy cost of an additional employee is equal to the value. Thus, hiring is determined by

$$
\kappa \nu_{t}^{j_{w}}=\left(1-s^{n e w}\right) \mu_{t} J_{t}\left(w_{t}^{j_{w}}\right)+s^{n e w} \mu_{t} J_{t}\left(w_{t}^{0}\right),
$$

where $\kappa$ is the cost of posting a vacancy. Note that this formulation builds on the assumption that filled vacancies become productive and receive a wage in the current period. If the share of new hires that receive a rebargained wage $\left(s^{n e w}\right)$ is zero, all new entrants enter into an existing wage structure. In the other extreme, where $s^{\text {new }}$ is equal to unity, newly hired workers always get a new wage.

One way to rationalize the wholesale firm concept, implicit in this specific formulation of the hiring decision, is considerations about fairness and reciprocity in the employer-employee relationship. Specifically, when $s^{\text {new }}$ is larger than zero, we can think of the wholesale firm as a firm with many departments and in constant reorganization. Each department belongs to a wage cohort and has its own decision power when it comes to questions about vacancy posting, wage bargaining and 
organization. Every time the department decides to hire, but not rebargain the wage for incumbent workers, the department splits in two and a new department is created for newly hired workers that get to bargain their wage. Whenever different departments within the wholesale firm enter into wage rebargaining simultaneously they are merged. This reorganization is done in order to keep an organizational (and possibly a physical) distance between workers that do similar work for different pay. By reorganizing, the wholesale firm can avoid the adverse effects on employer-employee relationships implied by workers perceiving wage differences for similar work as unfair. ${ }^{8}$

The employment flow between categories $n_{t}^{j_{w}}$ is given by

$$
n_{t}^{0}=\sum_{j_{w}=1}^{J_{w}-1} \rho \alpha_{t}^{j_{w}} n_{t-1}^{j_{w}-1}+\left(s^{n e w}+\left(1-s^{n e w}\right) \varpi_{t}^{0}\right) \mu_{t}
$$

and, for $j>0$,

$$
n_{t}^{j}=\rho\left(1-\alpha_{t}^{j_{w}}\right) n_{t-1}^{j_{w}-1}+\left(1-s^{n e w}\right) \varpi_{t}^{j_{w}} \mu_{t}
$$

\subsection{The Aggregate Resource Constraint}

Total demand is given by

$$
y_{t}^{d}=c_{t}+\kappa v_{t}-\Phi_{L} n_{t} .
$$

Total supply is $Y_{t}$. From market clearing on the labor market, we have

$$
\sum_{j=0}^{J-1} \omega_{t}^{j} Y_{t}^{j}=\sum_{j=0}^{J-1} \omega_{t}^{j}\left(\frac{P_{t}^{j}}{P_{t}}\right)^{-\sigma} Y_{t}=\sum_{j_{w}=0}^{J_{w}-1} n_{t}^{j_{w}} Z \bar{h}-\sum_{j=0}^{J-1} \omega_{t}^{j} \Xi_{j, t} .
$$

Combining the expression above with expression (53) and $Y_{t}=y_{t}^{d}$ gives the aggregate resource constraint

$$
\sum_{j=0}^{J-1} \omega_{t}^{j}\left(\frac{P_{t}^{j}}{P_{t}}\right)^{-\sigma}\left(c_{t}+\kappa v_{t}-\Phi_{L} n_{t}\right)=\sum_{j_{w}=0}^{J_{w}-1} n_{t}^{j_{w}} Z \bar{h}-\sum_{j=0}^{J-1} \omega_{t}^{j} \Xi_{j, t} .
$$

\subsection{Optimal Policy}

The policy maker needs to take into account several distortions when designing optimal policy. First, there is imperfect competition in the product market. There is also a distortion due to money demand and the cost of using credit. Furthermore, there are relative price and wage distortions. Finally, there are distortions in the hiring decision on the labor market. Here, we focus on the Ramsey policy as discussed by Schmitt-Grohe and Uribe (2004), maximizing welfare, subject to the constraints given

\footnotetext{
${ }^{8}$ See e.g. Bewley $(1999,2004)$ for empirical evidence on the link between perceived fairness and employer-employee relationships as well as on the limited comparison group used to form a perception of fairness.
} 
by optimizing agents in the economy, i.e., for example first-order and market clearing conditions.

The policy-maker then maximizes (23) subject to the constraints (14), (15), (29) the aggregate resource constraint (55), the flow equation of prices

$$
p_{t}^{j}=\frac{p_{t-1}^{j-1}}{1+\pi_{t}}
$$

expressions (9), (11), (19), (28), (32), (34), (42), (44), (46), (50), (51), (52) and the flow equation of wages

$$
w_{t}^{j}=\frac{w_{t-1}^{j-1}}{1+\pi_{t}}
$$

\section{Quantitative Evaluation}

\subsection{Calibration}

For our quantitative evaluation, we assume log preferences in consumption and leisure, i.e., $u\left(c_{t}\right)=$ $\log c_{t}$ and $\phi=1$. The baseline calibration of the structural parameters is chosen to represent the U.S. economy on a quarterly basis and is presented in Table 1 . We set $\beta$ to 0.9928 as in Khan, King, and

\begin{tabular}{lll}
\multicolumn{3}{c}{ Table 1: Baseline Calibration of the Model } \\
\hline \hline \multicolumn{3}{c}{ Parameters } \\
\hline$\beta$ & Time preference & 0.9928 \\
$\sigma$ & Product market substitutability & 10 \\
$\kappa^{L}$ & Disutility of working & 0.8487 \\
$\kappa$ & Vacancy-posting cost & 0.024 \\
$\rho$ & Match-retention rate & 0.9 \\
$b_{r}$ & Replacement payoff & 0.218 \\
$\varphi$ & Family bargaining power & 0.5 \\
$\sigma_{a}$ & Matching elasticity & 0.6 \\
$\sigma_{\mu}$ & Matching efficiency & 0.45 \\
$\Phi_{L}$ & Fixed labor cost & 0.0069 \\
$\Phi_{K}$ & Fixed capital cost & $1 / 3$ \\
$Z$ & Productivity shifter & 5 \\
$\bar{h}$ & Hours worked & 0.2 \\
\hline \hline
\end{tabular}

Wolman (2003). This generates a real interest rate of slightly below 3 percent and is motivated by data on one-year T-bill rates and the GDP deflator. Note that this is a key parameter for governing the strength of the monetary distortion. ${ }^{9}$ The cost distributions $G_{P}, G_{H}, G_{J}$ and $F$ follow the beta distribution and are described in appendix A. The parameters for $G_{P}$ and $F$ are calibrated following Lie (2010) closely and the parameters for the disagreement cost distributions $G_{H}$ and $G_{J}$ are chosen

\footnotetext{
${ }^{9}$ For example, using a lower number like $\beta=0.99$ would give the Ramsey planner an incentive to set a lower inflation rate.
} 
to generate a duration of wage contracts of one year; see appendix A for details. For $\sigma$ we use a standard value of 10, generating a markup of around 11 percent.

The value of $b_{r}$ implies a replacement rate of around 0.4 of the wage (in terms of utility, we set $\kappa^{L}$ so that our model calibration implies that unemployed workers gets about 70 percent of employed workers in replacement utility, where the disutility of effort is an important component in mitigating the difference). The parameter $\kappa$ implies that vacancy costs are around $0.2 \%$ of steady state output. We set the bargaining power $\varphi=0.5$, implying symmetrical bargaining in the baseline calibration. For the job separation rate $1-\rho$, we follow Hall (2005) and set $\rho=0.9$. The value of $\sigma_{a}$ is set to 0.6 and $\sigma_{\mu}$ is chosen to generate a probability of finding a job, $s$, of about 0.95 , as in Gertler, Sala, and Trigari (2008). As in Gertler, Sala, and Trigari (2008), we then get an employment rate of slightly above 0.9. We set $\Phi_{L}$ and $\Phi_{K}$ as in Christoffel, Kuester, and Linzert (2009). We set hours worked to 0.2 and $Z$ to 5 in order to normalize output per employee to unity.

To calibrate the share of new hires that get rebargained wages, there are several sources of evidence. Micro-data studies, summarized in Pissarides (2009), seem to indicate that newly hired workers' wages are substantially more flexible than incumbents' wages. However, answering the question if newcomers' wages are more cyclical than incumbents' wages is associated with severe identification problems. In particular, the studies summarized in Pissarides (2009) generally fail to control for effects stemming from variations in the composition of firms and match quality over the cycle. Thus, it might be that the empirical evidence just reflects that workers move from low-wage firms (low-quality matches) to high-wage firms (high-quality matches) in boom periods and vice versa in recessions. The approach taken to address this issue is to introduce job-specific fixed effects in a regression of individual wages on the unemployment rate and the interaction of the unemployment rate and dummy variable indicating if the tenure of the worker is short, see Gertler and Trigari (2009). This dummy structure controls for composition effects in workers, firms and match quality. The problem, however, is that the interaction effect is in this case only identified with the within-match variation. It answers the question whether wages for workers with short tenure responds more to cyclical factors than wages for workers with longer tenure after that the worker has already been hired. Albeit an interesting question in itself, it is not the question at hand. Thus, existing micro-data studies can only take us so far. If we instead turn to survey evidence, like Bewley (1999), Bewley (2007) for the U.S. and the study performed within the Eurosystem Wage Dynamics Network (WDN) covering about 17, 000 firms in 17 European countries, we see strong evidence of that the wages of new hires are tightly linked to those of incumbents. As reported by Galuscak, Keeney, Nicolitsas, Smets, Strzelecki, and Vodopivec (2010), about 80\% percent of the firms in the WDN survey respond that internal factors (like the internal pay structure) are more important in driving wages of new hires than external or market conditions. More direct evidence on 
the parameter we seek to calibrate is provided by Hall and Krueger (2008), who finds that between $25 \%$ and $50 \%$ of new hires receive posted wages and hence between $50 \%$ and $75 \%$ bargain over the wage. We therefore set $s^{\text {new }}$ to the midpoint of this interval, i.e., $\left(s^{\text {new }}=\right)$ 0.625. Note that the choices of $s^{\text {new }}$ are on the high side, since even if all workers get into an existing wage structure, a non-negligible share would enter firms where wages are rebargained. However, we investigate the effect on the results of varying this parameter.

Recalling the discussion from above, a necessary condition for our mechanism to be relevant is that the labor market outcome is inefficient. In the standard U.S. calibration of the model described above, employment is 2.85 percent lower than in the efficient allocation. To solve for the efficient allocation we maximize family welfare, as described in (23), subject to the matching function (33), the flow equation of employment $n_{t}=\rho n_{t-1}+\mu_{t}$ and the aggregate resource constraint

$$
c_{t}+\kappa v_{t}-\Phi_{L} n_{t}=n_{t} Z \bar{h}
$$

\subsection{Results}

In Table 2 we present the Ramsey optimal steady state inflation rates implied by our model. In the absence of price or wage rigidities we find, in line with previous literature, that the Ramsey optimal inflation rate is -2.8 percent per year. In other words, with no frictions to price or wage setting, the model replicates the finding of Friedman (1969), that deflation is optimal when there is a role for money as a medium of exchange.

Table 2: Yearly optimal inflation rate under the Ramsey policy

\begin{tabular}{lc}
\hline \hline & $\pi$ \\
\hline No Price or Wage Rigidities & -2.85 \\
State Dependent Prices only & -0.78 \\
State Dependent Prices and Wages & 1.11 \\
No monetary frictions (cashless) & 1.96 \\
Exogenous adjustment probabilities & 1.59 \\
\hline \hline
\end{tabular}

When introducing price rigidities, we see that the Ramsey optimal inflation rate increases, but remains below zero, as previous pointed out by Khan, King, and Wolman (2003) and Schmitt-Grohe and Uribe (2010). When also introducing impediments to continuous wage rebargaining, we see that the Ramsey optimal inflation rate increases significantly, from 0.78 percent deflation to an inflation rate of 1.11 percent a year. The reason is that the inflation rate has distributional effects in this model when nominal wages do not continuously adjust, as discussed in section 2 above.

Furthermore, we analyze the importance of endogenous price and wage adjustment probabilities by fixing the price and wage adjustment probabilities to the values under the Ramsey optimal policy. 
Then we solve for the Ramsey policy under these exogenous adjustment probabilities. The optimal inflation rate increases by around half a percentage point in this case, as compared to the case with endogenous adjustment probabilities. Thus, the ability of agents to self-select into adjustment has strong effects on the Ramsey planner's choice. Also, this result contrasts with Lie (2010), who finds that endogenizing adjustment probabilities is not important in a model with flexible wages.

Removing the monetary friction and looking at the cashless economy, as analyzed in Woodford (2003), increases inflation to slightly below two percent. Thus, the monetary distortion has a substantial effect on the optimal policy.

To explore the strength of the mechanism, we next vary the matching efficiency and the replacement rate. The results from this exercise can be seen in Table 3 . When the productivity of the matching function, $\sigma_{\mu}$, drops by half, the optimal inflation rate drops by slightly less than 0.2 percentage units. The reason is that an increase in firm values due to an increase in inflation now has a smaller effect on job creation incentives. The intuition behind this is that a given number of vacancies leads to fewer matches and in turn a lower probability of filling a vacancy. When the replacement rate parameter, $b_{r}$, is increased, the optimal inflation rate increases by close to half a percentage point. The intuition is that an increase in the replacement rate makes the economy less efficient, thus increasing the net gain for the Ramsey planner to use inflation to move the economy towards the efficient allocation. Moreover, the share of new hires receiving rebargained wages has a big effect, but only when the share is fairly close to one, as can be seen in Table 3. When the share is one the Ramsey policy implies a

Table 3: Yearly optimal inflation rate under the Ramsey policy

\begin{tabular}{ccccccc}
\hline \hline & Baseline & $\sigma_{\mu}^{\prime}=\frac{\sigma_{\mu}}{2}$ & $b_{r}^{\prime}=1.25 b_{r}$ & $s^{\text {new }}=1$ & $s^{\text {new }}=0.8$ & $s^{\text {new }}=0.5$ \\
State. Dep. & 1.11 & 0.97 & 1.47 & -0.77 & 0.45 & 1.35 \\
\hline \hline
\end{tabular}

deflation rate of 0.78 percent. If the share drops to 80 percent, the optimal inflation rate is about a half percent. Decreasing the share from 62.5 percent to 50 percent leads to a rather modest increase in the optimal inflation rate.

To take a further look at the underlying mechanism, we compute some key variables for different inflation rates. As illustrated in table 4 , firm values when filling a vacancy, $\lambda_{t} J_{x, t}$, increase in inflation and worker values when finding a job, $\lambda_{t} H_{x, t}\left(=\lambda_{t}\left(V_{x, t}-U_{t}\right)\right)$, decrease. ${ }^{10}$ This, in turn, leads to an increase in vacancy creation and employment. Since the steady-state labor market outcome is generally inefficient due to search and matching frictions, the average inflation rate can affect welfare in the economy via its effects on employment. Specifically, when increasing the inflation rate from a deflation rate of one percent to an inflation rate of two percent, the inefficiency gap in employment is

\footnotetext{
${ }^{10}$ That is, the values are expressed in utility terms in table 4 by multiplying by $\lambda_{t}$.
} 
Table 4: Steady-State Values, Job Finding Rate, Vacancy Filling Rate and Employment for Different Inflation Rates

\begin{tabular}{lccccccc}
\hline \hline & $\pi=2$ & $\pi=1.5$ & $\pi=1$ & $\pi=0.5$ & $\pi=0$ & $\pi=-0.5$ & $\pi=-1$ \\
Worker Value $\lambda_{t} H_{x, t}$ & 0.1610 & 0.1632 & 0.1667 & 0.1711 & 0.1760 & 0.1810 & 0.1856 \\
Firm Value $\lambda_{t} J_{x, t}$ & 0.1919 & 0.1896 & 0.1859 & 0.1811 & 0.1760 & 0.1709 & 0.1661 \\
Job Finding Rate & 0.9427 & 0.9392 & 0.9334 & 0.9259 & 0.9177 & 0.9094 & 0.9018 \\
Vacancy Filling Rate & 0.1484 & 0.1493 & 0.1506 & 0.1525 & 0.1545 & 0.1566 & 0.1586 \\
Employment & 0.9041 & 0.9038 & 0.9032 & 0.9025 & 0.9017 & 0.9009 & 0.9002 \\
\hline \hline
\end{tabular}

reduced by about 15 percent in the baseline calibration.

Finally, as a robustness exercise, we have also solved for the dynamics of the model to an autoregressive wholesale-firm technology shock. This is described in detail in appendix C.

\section{Concluding Discussion}

This paper explores how the interaction of nominal wage and labor market search and matching frictions can affect the planner's trade-off when choosing the Ramsey optimal inflation rate. The framework for our quantitative evaluation features many of the aspects that have been deemed important in determining the optimal inflation rate. Specifically, a transaction cost and relative price distortions. In addition to these features, we also add search frictions in the labor market and impediments to continuous wage rebargaining.

We find that the Ramsey optimal inflation rate in the baseline calibration is 1.11 percent per year. The reason for this high rate is that the planner uses the inflation rate to govern vacancy creation through the distributional effects of inflation on wage bargaining. These results are sensitive to variation in some of the labor market parameters. When shutting down the monetary distortion and looking at the cashless economy, as analyzed in Woodford (2003), we find that the Ramsey optimal inflation rate increases to 1.96 percent. Thus, the monetary distortion has a substantial effect on the Ramsey planner's choice.

Variation in the share of new hires receiving rebargained wages has a substantial effect on the optimal inflation rate. When 80 percent of the newly hired workers receive new wages the optimal inflation rate is 0.45 percent and when 50 percent of newly hired workers receive new wages the optimal inflation rate is 1.35 percent. If all newly hired workers receive rebargained wages the optimal inflation rate is about -0.78 percent.

The findings from the baseline model are conditional on the agents choosing when to adjust prices and wages. To address the importance of endogenous timing of price and wage setting, we fix the price- and wage-adjustment probabilities so that they are equal to those under the Ramsey policy when price and wage adjustment probabilities are endogenous. When probabilities are exogenous, 
we find a Ramsey optimal inflation rate of 1.59 percent. Thus, exogenous timing of rebargaining increases the Ramsey optimal inflation rate by almost half a percentage point relative to the case with endogenous adjustment hazards. Overall, we show that the combination of nominal wage- and search and matching frictions can generate a Ramsey optimal inflation that is significantly positive. 


\section{References}

Adam, K., And R. Billi (2006): "Optimal Monetary Policy under Commitment with a Zero Bound on Nominal Interest Rates," Journal of Money, Credit and Banking, 38, 1877-1905.

Bewley, T. (1999): Why Wages Don't Fall During a Recession. Harvard University Press, Cambridge, MA.

— (2004): "Fairness, Reciprocity, and Wage Rigidity," IZA DP No. 1137.

— (2007): "Insights Gained from Conversations with Labor Market Decision Makers," ECB Working Paper 776 .

BILli, R. (2011): "Optimal Inflation for the US Economy," American Economic Journal: Macroeconomics, 3, 29-52.

Christoffel, K., K. Kuester, and T. Linzert (2009): "The Role of Labor Markets for Euro Area Monetary Policy," European Economic Review, 53, 908-936.

Dotsey, M., R. King, and A. Wolman (1999): "State-Dependent Pricing and the General Equilibrium Dynamics of Money and Output," Quarterly Journal of Economics, 114, 655-690.

Erceg, C., D. Henderson, and A. Levin (2000): "Optimal Monetary Policy with Staggered Wage and Price Contracts," Journal of Monetary Economics, 46, 281-313.

FAiA, E. (2009): "Ramsey Monetary Policy with Labour Market Frictions," mimeo, Goethe University.

FaiA, E., And L. Rossi (2009): "Unions Power, Collective Bargaining and Optimal Monetary Policy," mimeo, Goethe University.

Friedman, M. (1969): "The Optimum Quantity of Money," in The Optimum Quantity of Money, and Other Essays. Aldine Publishing Company, Chicago, IL.

Galuscak, K., M. Keeney, D. Nicolitsas, F. Smets, P. Strzelecki, and M. Vodopivec (2010): "The Determination of Wages of Newly Hired Employees: Survey Evidence on Internal versus External Factors," ECB Working Paper 1153.

Gertler, M., L. Sala, and A. Trigari (2008): "An Estimated Monetary DSGE Model with Unemployment and Staggered Nominal Wage Bargaining," Journal of Money, Credit and Banking, 40, 1713-1764.

Gertler, M., and A. Trigari (2009): "Unemployment Fluctuations With Staggered Nash Wage Bargaining," Journal of Political Economy, 117, 38-86. 
Hall, R. (2005): "Employment Fluctuations with Equilibrium Wage Stickiness," American Economic Review, 95(1), 50-65.

Hall, R., and A. Krueger (2008): "Wage Formation between Newly Hired Workers and Employers: Survey Evidence," NBER WP No. 14329.

Haller, H., And S. Holden (1990): "A Letter to the Editor on Wage Bargaining," Journal of Economic Theory, 52, 232-236.

Holden, S. (1994): "Wage Bargaining and Nominal Rigidities," European Economic Review, 38, 1021-1039.

Khan, A., R. King, and A. Wolman (2003): "Optimal Monetary Policy," Review of Economic Studies, 70, 825-860.

Kim, J., And F. Ruge-Murcia (2011): "Monetary Policy when Wages are Downwardly Rigid: Friedman Meets Tobin,” Journal of Economic Dynamics and Control, 35, 2064-2077.

Lie, D. (2010): "State-Dependent Pricing and Optimal Monetary Policy," Federal Reserve Bank of Boston Working Paper 09-22.

Merz, M. (1995): "Search in the Labor Market and the Real Business Cycle Model," Journal of Monetary Economics, 36, 269-300.

Mortensen, D., and C. Pissarides (1994): "Job Creation and Job Destruction in the Theory of Unemployment," Review of Economic Studies, 61, 397-415.

Pissarides, C. (2009): "The Unemployment Volatility Puzzle: Is Wage Stickiness the Answer?," Econometrica, 77(5), 1339-1369.

Rubinstein, A. (1982): "Perfect Equilibrium in a Bargaining Model," Econometrica, 50, 97-109.

Schmitt-Grohe, S., And M. Uribe (2004): "Optimal Fiscal and Monetary Policy under Sticky Prices," Journal of Economic Theory, 114, 198-230.

Schmitt-Grohé, S., And M. Uribe (2005): "Optimal Fiscal and Monetary Policy in a Medium-Scale Macroeconomic Model," NBER Working Paper No.11417.

Schmitt-Grohe, S., and M. Uribe (2009): "On Quality Bias and Inflation Targets," NBER WP No. 15505.

(2010): "The Optimal Rate of Inflation," in Handbook of Macroeconomics, ed. by M. Friedman, B. M.and Woodford, vol. 3B. Elsevier, San Diego, CA.

(2011): "Foreign Demand for Domestic Currency and the Optimal Rate of Inflation," forthcoming Journal of Money, Credit, and Banking. 
Thomas, C. (2008): "Search and Matching Frictions and Optimal Monetary Policy," Journal of Monetary Economics, 55, 936-956.

Trigari, A. (2009): "Equilibrium Unemployment, Job Flows, and Inflation Dynamics," Journal of Money, Credit and Banking, 41(1), 1-33.

Woodford, M. (2003): Interest and Prices: Foundations of a Theory of Monetary Policy. Princeton University Press, Princeton, NJ. 


\section{Appendix}

\section{A Adjustment Cost Distributions}

As in Lie (2010), we use the beta distribution for the distribution of price adjustment costs. The probability density function of the beta distribution is

$$
g^{b e t a}\left(x ; a_{l}, a_{r}\right)=\frac{1}{\beta\left(a_{l}, a_{r}\right)} x^{a_{l}-1}(1-x)^{a_{r}-1},
$$

with cumulative distribution $G^{\text {beta }}$. Since the support of the cost distributions do not have an upper bound equal to one, we normalize the support by the upper bounds of the distributions. Specifically, we set

$$
g_{P}\left(v ; a_{l}, a_{r}, \Omega_{P}\right)=g^{b e t a}\left(\frac{v}{\Omega_{P}} ; a_{l}, a_{r}\right) .
$$

Note that we set $\Omega_{P}$ differently than Lie (2010), to generate a duration of prices of about 3 quarters at an inflation rate of 2 percent. Similarly, for the disagreement cost distributions, we set

$$
g_{J}\left(v ; a_{l}^{J}, a_{r}^{J}, \Omega_{J}\right)=g^{b e t a}\left(\frac{v}{\Omega_{J}} ; a_{l}^{J}, a_{r}^{J}\right)
$$

and

$$
g_{H}\left(v ; a_{l}^{H}, a_{r}^{H}, \Omega_{H}\right)=g^{b e t a}\left(\frac{v}{\Omega_{H}} ; a_{l}^{H}, a_{r}^{H}\right) .
$$

Finally, we model the credit cost distribution also following Lie (2010). Specifically, we set

$$
F(x)=1-\hat{\xi}+\hat{\xi} F^{b e t a}\left(\frac{x}{\Omega_{c}} ; a_{l}^{c}, a_{r}^{c}\right)
$$

where $1-\hat{\xi}$ is the share of goods with zero credit costs.

The calibration is described in detail in the table below.

\section{B Wage Adjustment Probabilities}

The fraction of firms that calls a conflict is

$$
\begin{array}{cc}
1 & \text { if } \Omega_{J}<d J_{t}^{j_{w}}\left(w_{t}^{j_{w}}\right), \\
G_{J}\left(d J_{t}^{j_{w}}\left(w_{t}^{j_{w}}\right)\right) & 0 \leq d J_{t}^{j_{w}}\left(w_{t}^{j_{w}}\right) \leq \Omega_{J}, \\
0 & d J_{t}^{j_{w}}\left(w_{t}^{j_{w}}\right)<0 .
\end{array}
$$


Table 5: Calibration of adjustment cost parameters

\begin{tabular}{lll}
\hline \hline \multicolumn{1}{c}{ Parameters } \\
\hline$a_{l}$ & Beta left parameter (prices) & 2.1 \\
$a_{r}$ & Beta right parameter (prices) & 1 \\
$\Omega_{P}$ & The largest fixed cost (prices) & 0.01 \\
$a_{l}^{J}=a_{l}^{H}$ & Beta left parameter (wages) & 2.1 \\
$a_{r}^{J}=a_{r}^{H}$ & Beta right parameter (wages) & 1 \\
$\Omega_{J}=\Omega_{H}$ & The largest fixed cost (wages) & 0.098 \\
$a_{l}^{c}$ & Beta left parameter (credit) & 2.806 \\
$a_{r}^{c}$ & Beta right parameter (credit) & 10.446 \\
$\Omega_{c}$ & The largest fixed cost (credit) & 0.013 \\
$\hat{\xi}$ & Mass of goods with positive credit cost & 0.361 \\
\hline \hline
\end{tabular}

Similarly, the fraction of workers that has an incentive to call a conflict to force a rebargain of the wage contract is

$$
\begin{array}{cc}
1 & \text { if } \Omega_{H}<d H_{t}^{j_{w}}\left(w_{t}^{j_{w}}\right), \\
G_{H}\left(d H_{t}^{j_{w}}\left(w_{t}^{j_{w}}\right)\right) & 0 \leq d H_{t}^{j_{w}}\left(w_{t}^{j_{w}}\right) \leq \Omega_{H}, \\
0 & d H_{t}^{j_{w}}\left(w_{t}^{j_{w}}\right)<0 .
\end{array}
$$

The adjustment probabilities are then

$$
\alpha_{t}^{j_{w}}=\left\{\begin{array}{cc}
1 & \text { if } \Omega_{J}<d J_{t}^{j_{w}}\left(w_{t}^{j_{w}}\right) \text { or if } \Omega_{H}<d H_{t}^{j_{w}}\left(w_{t}^{j_{w}}\right), \\
G_{J}\left(d J_{t}^{j_{w}}\left(w_{t}^{j_{w}}\right)\right)+G_{J}\left(d H_{t}^{j_{w}}\left(w_{t}^{j_{w}}\right)\right) & 0 \leq d J_{t}^{j_{w}}\left(w_{t}^{j_{w}}\right) \leq \Omega_{J} \\
-G_{H}\left(d H_{t}^{j_{w}}\left(w_{t}^{j_{w}}\right)\right) G_{J}\left(d J_{t}^{j_{w}}\left(w_{t}^{j_{w}}\right)\right) & \text { and } 0 \leq d H_{t}^{j_{w}}\left(w_{t}^{j_{w}}\right) \leq \Omega_{H}, \\
G_{J}\left(d J_{t}^{j_{w}}\left(w_{t}^{j_{w}}\right)\right) & 0 \leq d J_{t}^{j_{w}}\left(w_{t}^{j_{w}}\right) \leq \Omega_{J} \text { and } d H_{t}^{j_{w}}\left(w_{t}^{j_{w}}\right)<0, \\
G_{H}\left(d H_{t}^{j_{w}}\left(w_{t}^{j_{w}}\right)\right) & d J_{t}^{j_{w}}\left(w_{t}^{j_{w}}\right)<0 \text { and } 0 \leq d H_{t}^{j_{w}}\left(w_{t}^{j_{w}}\right) \leq \Omega_{H}, \\
0 & d J_{t}^{j_{w}}\left(w_{t}^{j_{w}}\right)<0 \text { and } d H_{t}^{j_{w}}\left(w_{t}^{j_{w}}\right)<0 .
\end{array}\right.
$$

The derivative of the family value function is then, using expressions (42) and (44),

$$
\begin{aligned}
\frac{d H_{t}^{j_{w}}\left(w_{t}^{j_{w}}\right)}{d W^{0}} \frac{1}{P_{t}}= & \frac{1}{P_{t}}+\beta E_{t} \frac{\lambda_{t+1}}{\lambda_{t}} \rho\left(1-\alpha_{t+1}^{j_{w}+1}\right) \frac{d H_{t+1}^{j_{w+1}}\left(w_{t+1}^{j_{w}+1}\right)}{d W^{0}} \frac{1}{P_{t+1}} \\
& -E_{t}\left[\left(\frac{d \alpha_{t+1}^{j_{w}+1}}{d H_{t}\left(w_{t}^{j_{w}}\right)} \frac{d H_{t+1}^{j_{w+1}}\left(w_{t+1}^{j_{w}+1}\right)}{d W^{0}} \frac{1}{P_{t+1}}+\frac{d \alpha_{t+1}^{j_{w}+1}}{d J_{t}\left(w_{t}^{j_{w}}\right)} \frac{d J_{t+1}^{j_{w+1}}\left(w_{t+1}^{j_{w}+1}\right)}{d W^{0}} \frac{1}{P_{t+1}}\right)\right. \\
& \left.\times \beta \rho \frac{\lambda_{t+1}}{\lambda_{t}}\left(H_{t+1}^{j_{w}+1}\left(w_{t+1}^{j_{w}+1}\right)-H_{t+1}^{0}\left(w_{t+1}^{0}\right)\right)\right] .
\end{aligned}
$$


Multiplying by $\lambda_{t} W^{0}$ gives

$$
\begin{aligned}
\frac{d H_{t}^{j_{w}}\left(w_{t}^{j_{w}}\right)}{d W^{0}} \lambda_{t} W^{0} \frac{1}{P_{t}}= & \frac{\lambda_{t} W^{0}}{P_{t}}+\beta E_{t} \lambda_{t+1} \rho\left(1-\alpha_{t+1}^{j_{w}+1}\right) \frac{d H_{t+1}^{j_{w+1}}\left(w_{t+1}^{j_{w}+1}\right)}{d W^{0}} \frac{W^{0}}{P_{t+1}} \\
& -E_{t}\left[\left(\frac{d \alpha_{t+1}^{j_{w}+1}}{d H_{t}\left(w_{t}^{j_{w}}\right)} \frac{d H_{t+1}^{j_{w+1}}\left(w_{t+1}^{j_{w}+1}\right)}{d W^{0}} \frac{W^{0}}{P_{t+1}}+\frac{d \alpha_{t+1}^{j_{w}+1}}{d J_{t}\left(w_{t}^{j_{w}}\right)} \frac{d J_{t+1}^{j_{w+1}}\left(w_{t+1}^{j_{w}+1}\right)}{d W^{0}} \frac{W^{0}}{P_{t+1}}\right)\right. \\
& \left.\times \beta \rho \lambda_{t+1}\left(H_{t+1}^{j_{w}+1}\left(w_{t+1}^{j_{w}+1}\right)-H_{t+1}^{0}\left(w_{t+1}^{0}\right)\right)\right] .
\end{aligned}
$$

\section{Dynamics}

In this appendix we introduce a multiplicative $A R(1)$ technology process (with an AR coefficient of $0.9)$ to the production technology of wholesale firms, i.e. in equation (43), to illustrate the dynamic solution to the quantitative model presented above. In Figure 1, we plot the Ramsey optimal policy paths of consumption, inflation and the nominal interest rate (in terms of deviation from the steady state) to a one percent persistent technology shock in the models with staggered nominal wages, and flexible wages, respectively. Note that in the latter model the interaction mechanism between search and matching frictions and staggered wages is turned off. It is reassuring to see that both models have well-specified dynamics, thus confirming that the baseline calibration makes sense in a dynamic setting as well.

When comparing the policy paths across models, we see that they differ to some extent. Specifically, the interest rate and inflation are relatively more responsive in the model with wage frictions, while the response of consumption is rather similar across models. We also plot the price and wage adjustment shares. The change in the share of firms adjusting the price is smaller in the model with only price frictions than in the model with both price and wage frictions. The share adjusting the wage responds positively in the model with wage frictions as the optimal wage increases in productivity. Note also that the share adjusting the wage always is one when wages are flexible. The reason for the response of the adjustment shares can be seen by first noting that an increase in productivity leads to an increase in the optimal real wage while it leads to a decrease in the optimal relative price (due to a decrease in marginal costs). With both price and wage staggering, the relative price falls in the duration of the contract, since steady-state inflation is positive. The actual relative price in firms with a duration of more than one period thus comes closer to the optimal relative price and hence adjustment probabilities decrease (with only price staggering the relative price increases in the duration of the contract since the Ramsey policy then prescribes steady-state deflation). On the other hand, since the real wage also falls in the duration of the contract, the actual real wage in contracts that has lasted more than one period is now further away from the optimal real wage, giving workers stronger incentives to induce 

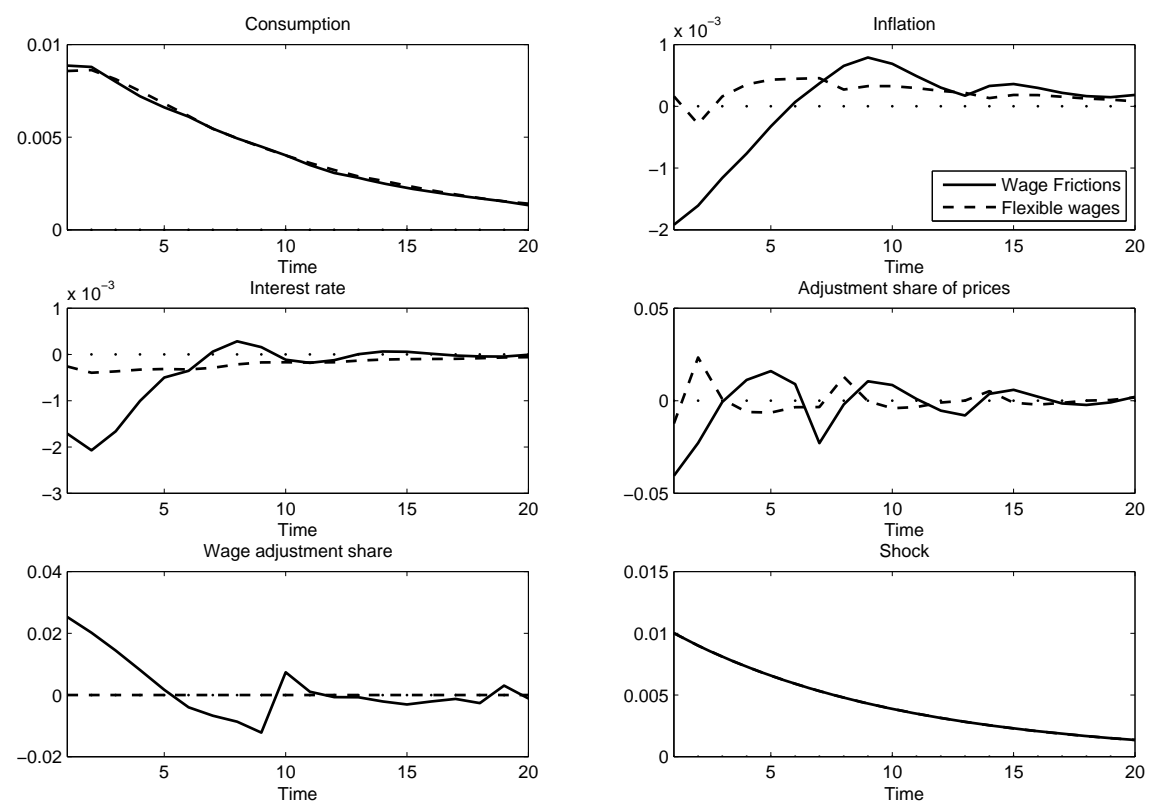

Figure 1: Impulse responses (deviations from steady state) to a one percent persistent technology shock in the models with wage frictions and flexible wages.

bargaining under disagreement, which in turn increases adjustment probabilities. 


\section{Earlier Working Papers:}

For a complete list of Working Papers published by Sveriges Riksbank, see www.riksbank.se

Estimation of an Adaptive Stock Market Model with Heterogeneous Agents by Henrik Amilon ........ 2005:177

Some Further Evidence on Interest-Rate Smoothing: The Role of Measurement

Errors in the Output Gap by Mikael Apel and Per Jansson.....

Bayesian Estimation of an Open Economy DSGE Model with Incomplete Pass-Through

by Malin Adolfson, Stefan Laséen, Jesper Lindé and Mattias Villani

Are Constant Interest Rate Forecasts Modest Interventions? Evidence from

an Estimated Open Economy DSGE Model of the Euro Area by Malin Adolfson,

Stefan Laséen, Jesper Lindé and Mattias Villani

Inference in Vector Autoregressive Models with an Informative

Prior on the Steady State by Mattias Villani

Bank Mergers, Competition and Liquidity by Elena Carletti, Philipp Hartmann

and Giancarlo Spagnolo

Testing Near-Rationality using Detailed Survey Data

by Michael F. Bryan and Stefan Palmqvist....

Exploring Interactions between Real Activity and the Financial Stance

by Tor Jacobson, Jesper Lindé and Kasper Roszbach

Two-Sided Network Effects, Bank Interchange Fees,

and the Allocation of Fixed Costs by Mats A. Bergman

Trade Deficits in the Baltic States: How Long Will the Party Last?

by Rudolfs Bems and Kristian Jönsson.

Real Exchange Rate and Consumption Fluctuations follwing Trade Liberalization

Modern Forecasting Models in Action: Improving Macroeconomic Analyses at Central Banks

by Malin Adolfson, Michael K. Andersson, Jesper Lindé, Mattias Villani and Anders Vredin.

Bayesian Inference of General Linear Restrictions on the Cointegration Space by Mattias Villani ....... 2005:189

Forecasting Performance of an Open Economy Dynamic Stochastic General Equilibrium Model

by Malin Adolfson, Stefan Laséen, Jesper Lindé and Mattias Villani

Forecast Combination and Model Averaging using Predictive Measures

by Jana Eklund and Sune Karlsson

Swedish Intervention and the Krona Float, 1993-2002

by Owen F. Humpage and Javiera Ragnartz....

A Simultaneous Model of the Swedish Krona, the US Dollar and the Euro

by Hans Lindblad and Peter Sellin....

2006:193

Testing Theories of Job Creation: Does Supply Create Its Own Demand?

by Mikael Carlsson, Stefan Eriksson and Nils Gottfries....

Down or Out: Assessing The Welfare Costs of Household Investment Mistakes

by Laurent E. Calvet, John Y. Campbell and Paolo Sodini

Efficient Bayesian Inference for Multiple Change-Point and Mixture Innovation Models

by Paolo Giordani and Robert Kohn

Derivation and Estimation of a New Keynesian Phillips Curve in a Small Open Economy

by Karolina Holmberg....

Technology Shocks and the Labour-Input Response: Evidence from Firm-Level Data

by Mikael Carlsson and Jon Smedsaas

Monetary Policy and Staggered Wage Bargaining when Prices are Sticky

by Mikael Carlsson and Andreas Westermark

The Swedish External Position and the Krona by Philip R. Lane

2006:200

Price Setting Transactions and the Role of Denominating Currency in FX Markets

by Richard Friberg and Fredrik Wilander....

2007:201

The geography of asset holdings: Evidence from Sweden

by Nicolas Coeurdacier and Philippe Martin

Evaluating An Estimated New Keynesian Small Open Economy Model

by Malin Adolfson, Stefan Laséen, Jesper Lindé and Mattias Villani .....

The Use of Cash and the Size of the Shadow Economy in Sweden

by Gabriela Guibourg and Biörn Segendorf

Bank supervision Russian style: Evidence of conflicts between micro- and macro-

prudential concerns by Sophie Claeys and Koen Schoors 
Optimal Monetary Policy under Downward Nominal Wage Rigidity

by Mikael Carlsson and Andreas Westermark.

Financial Structure, Managerial Compensation and Monitoring

by Vittoria Cerasi and Sonja Daltung

Financial Frictions, Investment and Tobin's q by Guido Lorenzoni and Karl Walentin

Sticky Information vs. Sticky Prices: A Horse Race in a DSGE Framework

by Mathias Trabandt.

Acquisition versus greenfield: The impact of the mode of foreign bank entry

on information and bank lending rates by Sophie Claeys and Christa Hainz

Nonparametric Regression Density Estimation Using Smoothly Varying Normal Mixtures

by Mattias Villani, Robert Kohn and Paolo Giordani

The Costs of Paying - Private and Social Costs of Cash and Card

by Mats Bergman, Gabriella Guibourg and Biörn Segendorf....

Using a New Open Economy Macroeconomics model to make real nominal

exchange rate forecasts by Peter Sellin

Introducing Financial Frictions and Unemployment into a Small Open Economy Model

by Lawrence J. Christiano, Mathias Trabandt and Karl Walentin

Earnings Inequality and the Equity Premium by Karl Walentin

2007:215

Bayesian forecast combination for VAR models by Michael K Andersson and Sune Karlsson.

2007:216

Do Central Banks React to House Prices?

by Daria Finocchiaro and Virginia Queijo von Heideken

The Riksbank's Forecasting Performance

by Michael K. Andersson, Gustav Karlsson and Josef Svensson

2007:218

Macroeconomic Impact on Expected Default Freqency

by Per Åsberg and Hovick Shahnazarian

Monetary Policy Regimes and the Volatility of Long-Term Interest Rates

by Virginia Queijo von Heideken

Governing the Governors: A Clinical Study of Central Banks

by Lars Frisell, Kasper Roszbach and Giancarlo Spagnolo .....

The Monetary Policy Decision-Making Process and the Term Structure of Interest Rates

by Hans Dillén

How Important are Financial Frictions in the U.S. and the Euro Area

by Virginia Queijo von Heideken

Block Kalman filtering for large-scale DSGE models by Ingvar Strid and Karl Walentin

Optimal Monetary Policy in an Operational Medium-Sized DSGE Model

by Malin Adolfson, Stefan Laséen, Jesper Lindé and Lars E.O. Svensson

Firm Default and Aggregate Fluctuations by Tor Jacobson, Rikard Kindell, Jesper Lindé and Kasper Roszbach

Re-Evaluating Swedish Membership in EMU: Evidence from an Estimated Model

by Ulf Söderström

The Effect of Cash Flow on Investment: An Empirical Test of the Balance Sheet Channel

by Ola Melander.

Expectation Driven Business Cycles with Limited Enforcement

by Karl Walentin

Effects of Organizational Change on Firm Productivity

by Christina Håkanson

Evaluating Microfoundations for Aggregate Price Rigidities: Evidence from Matched Firm-Level

Data on Product Prices and Unit Labor Cost by Mikael Carlsson and Oskar Nordström Skans

Monetary Policy Trade-Offs in an Estimated Open-Economy DSGE Mode

by Malin Adolfson, Stefan Laséen, Jesper Lindé and Lars E.O. Svensson

Flexible Modeling of Conditional Distributions Using Smooth Mixtures of Asymmetric

Student T Densities by Feng Li, Mattias Villani and Robert Kohn.

Forecasting Macroeconomic Time Series with Locally Adaptive Signal Extraction

by Paolo Giordani and Mattias Villani.

Evaluating Monetary Policy by Lars E.O. Svensson

2009:235 
Risk Premiums and Macroeconomic Dynamics in a Heterogeneous Agent Model by Ferre De Graeve, Maarten Dossche, Marina Emiris, Henri Sneessens and Raf Wouters..... $2010: 236$

Picking the Brains of MPC Members by Mikael Apel, Carl Andreas Claussen and Petra Lennartsdotter.

Involuntary Unemployment and the Business Cycle by Lawrence J. Christiano,

Mathias Trabandt and Karl Walentin

Housing collateral and the monetary transmission mechanism by Karl Walentin and Peter Sellin.

The Discursive Dilemma in Monetary Policy by Carl Andreas Claussen and Øistein Røisland.

Monetary Regime Change and Business Cycles by Vasco Cúrdia and Daria Finocchiaro 2010:241 Bayesian Inference in Structural Second-Price common Value Auctions by Bertil Wegmann and Mattias Villani

Equilibrium asset prices and the wealth distribution with inattentive consumers

by Daria Finocchiaro.

Identifying VARs through Heterogeneity: An Application to Bank Runs

by Ferre De Graeve and Alexei Karas.

Modeling Conditional Densities Using Finite Smooth Mixtures

by Feng Li, Mattias Villani and Robert Kohn

The Output Gap, the Labor Wedge, and the Dynamic Behavior of Hours

by Luca Sala, Ulf Söderström and Antonella Trigari

Density-Conditional Forecasts in Dynamic Multivariate Models

by Michael K. Andersson, Stefan Palmqvist and Daniel F. Waggoner

Anticipated Alternative Policy-Rate Paths in Policy Simulations

by Stefan Laséen and Lars E.O. Svensson

MOSES: Model of Swedish Economic Studies by Gunnar Bårdsen, Ard den Reijer

Patrik Jonasson and Ragnar Nymoen

The Effects of Endogenuos Firm Exit on Business Cycle Dynamics and Optimal

Fiscal Policy by Lauri Vilmi

Parameter Identification in a Estimated New Keynesian Open Economy Model

by Malin Adolfson and Jesper Lindé.....

Up for count? Central bank words and financial stress by Marianna Blix Grimaldi

Wage Adjustment and Productivity Shocks

by Mikael Carlsson, Julián Messina and Oskar Nordström Skans

Stylized (Arte) Facts on Sectoral Inflation by Ferre De Graeve and Karl Walentin

Hedging Labor Income Risk by Sebastien Betermier, Thomas Jansson,

Christine A. Parlour and Johan Walden

Taking the Twists into Account: Predicting Firm Bankruptcy Risk with Splines of Financial Ratios by Paolo Giordani, Tor Jacobson, Erik von Schedvin and Mattias Villani .... $2011: 256$

Collateralization, Bank Loan Rates and Monitoring: Evidence from a Natural Experiment by Geraldo Cerqueiro, Steven Ongena and Kasper Roszbach.....

On the Non-Exclusivity of Loan Contracts: An Empirical Investigation

by Hans Degryse, Vasso loannidou and Erik von Schedvin 
Sveriges Riksbank

Visiting address: Brunkebergs torg 11

Mail address: se-103 37 Stockholm

Website: www.riksbank.se

Telephone: +46878700 00, Fax: +468210531

E-mail: registratorn@riksbank.se 